\title{
The First Great Divergence? ${ }^{1}$
}

\author{
R. I. Moore*
}

The >Papal Revolution ` in late eleventh and early twelfth century western Europe and the unsuccessful campaign by Wang An Shi and his followers to reform the imperial administration of Song China at just the same time are regarded as critical turning points in their respective histories. They are strikingly similar in some crucial respects. Both represented the responses of dominant elites to fundamental challenges to their traditional positions. Similar crises seem to have occurred at the same period in other citied regions of Eurasia. Each resulted, to varying degrees, in the emergence of a new or newly defined learned elite which drew its authority from its role as custodian and interpreter of a body of texts and associated ritual practices held to have been inherited from antiquity or late antiquity. The cultural hegemonies thus established in their respective regions endured until c. 1800 or later, constituting the >civilizations , which are seen as the building blocks of modern world history.

I have argued that in Latin Europe the crisis gave birth to an enduring clerical elite whose members accorded over-riding loyalty to nascent governing institutions in church and state rather than to their kin. Elsewhere the cultural power of the learned was essentially directed to sustaining the interests of their kingroups. In 2009, borrowing the phraseology of Kenneth Pomeranz, I suggested that these contrasting outcomes constituted a >First Great Divergence between western Europe and the other Eurasian scivilizations،. In this paper the appropriateness of that description is reconsidered and dismissed, as embodying a simplistic teleological polarisation of the kind that Pomeranz had rightly rejected. Rather, it is suggested that the outcome of the general - though not universal - crisis of elites in early second-millennium Eurasia would be better described as a Great Diversification.

Keywords: Rise of the West; East-West Divergence; Europe and China; Middle Ages; bureaucracy; clerical elites; gentry.

A couple of generations ago every student of western European history was taught that one of its formative episodes was the scene at Canossa in 1077, when the Emperor Henry IV knelt in the snow to seek absolution from Pope Gregory VII. This, they were told, was a decisive moment in the struggle of the church for freedom from the lay control which had irredeemably corrupted the clergy and reduced the sacraments to objects of commerce. Cardinal Humbert of Moyenmoutier had written the manifesto for that struggle in his Three Books Against the Simoniacs of 1058; the Roman papacy had been irrevocably committed to it by the pontificates of Alexander II (1062-73) and his successor Gregory VII. Gregory died in 1085, defeated and driven from Rome despite his triumph at Canossa. The bitter struggle in which he had embroiled most of Europe, remembered by posterity as the Gregorian

* Correspondence Details: Professor R.I.Moore, School of History, Classics and Archaeology, Newcastle University, Newcastle on Tyne NE1 7RU, email: R.I.Moore@ncl.ac.uk.

1 Based on a paper presented at "New Perspectives on Comparative Medieval History: China and Europe, 8001600 «, (Pembroke College, Oxford, 30 September-1 October 2013). I am most grateful to the organisers, Hilde de Weert and Franz-Julius Morche, and the participants, for the invitation and their responses. 
(or papal) Reform raged on. It was a close-run thing, but by the middle of the twelfth century the reformers had secured control of the papacy. Their goals and the conception of the nature and conditions of clerical office which they embodied thenceforth prevailed unchallenged. In 1215, at the Fourth Lateran Council, their successors drew together the programme, doctrines and achievements of the past century and a half, consolidating and greatly extending the role of the clergy in every aspect of personal life and public affairs. ${ }^{2}$

1077 was also the year in which Wang An Shih, first Counsellor to Emperor Zhao Xu, was forced into retirement by the opponents of the New Policies which he had outlined in his Myriad Word Proposal of 1058, and begun to implement vigorously ten years later when he acceeded to the highest office. Zhao Xu, like Gregory VII, died in 1085, and under his successor the opponents of the New Policies, led by the historian Sima Guang, consolidated their ascendency at court. But Wang's disciples, like Gregory's, kept up the struggle, and several times regained the advantage, until the death of their last effective leader in $1155 .{ }^{3}$

The chronological coincidences between the two conflicts are alluring, and could easily be multiplied, but the coincidences are much more than chronological. The key goal of the European reformers was to restore the fitness of the clergy for its office. The church, they insisted, could fulfill its mission only with a clergy freed by celibacy from worldly ties and passions, and appointed, ordained and beneficed not by lay magnates but by its ecclesiastical superiors, on the grounds of spiritual fitness alone. ${ }^{4}$ Wang An Shi's goal was to mould the shih (the learned elite, constituted and defined by success in the examinations for positions in the imperial bureaucracy) into a closely knit managerial corps, co-extensive with an imperial government whose functions would be greatly extended at all levels. Only through such a body, trained and carefully selected for the purpose, he maintained, could general well-being be created and the security of the empire guaranteed. Sima Guang and his supporters complained that Wang's policies destroyed traditional divisions of responsibility, both within the imperial government and, more importantly, between the imperial government and the private domain. Government had no business to interfere in subjects' pursuit of their material interests, Sima insisted, and in doing so threatened the social order, weakened the mutually advantageous inter-dependence of rich and poor, eroded the responsibilities of the family, and undermined the traditional elite whose stability maintained order and underpinned the imperial regime itself. ${ }^{5}$

The eventual success of the papal reforms, including a dramatic sharpening of the theological and political differences between the Latin and the Greek churches, has made their objectives appear to historians as a natural, almost an inevitable step in the unfolding development of Christendom, or Europe, or the West. In the eleventh century, however, rreform posed just as radical a threat to the existing social and political order as Wang's New Policies. Church lands and the offices that controlled them formed a substantial proportion of the wealth of every region. At the millennium the concentration and interchangeability of these resources in the hands of magnate families constituted the indispensable basis of local hegemonies throughout western Europe. Conversely, the demand for sreform ‘ threatened the destruction of such hegemonies, entailing a clear and absolute division between secular and 
ecclesiastical lands, offices and revenues. Resolution was achieved only after two centuries of bitter and often bloody struggle at every level, through acceptance of the celibacy of the clergy on the one hand, and on the other of strictly monogamous marriage and the severe restriction of rights of inheritance, for example (but by no means always) to the eldest legitimate son alone. The consequent transformation of the family structures and way of life of the nobility were sustained by the promulgation of new forms of piety and spirituality and the development of a new vernacular culture. ${ }^{6}$

The subordination of local hegemony to larger political and ideological structures thus forms the central, and revolutionary, theme of western European history in the eleventh and twelfth centuries. It was just such a hegemony that Sima Guang and his followers defended successfully against the claims of imperial government in China. In both cases the issue was between the proponents of centrally promulgated and directed sreform ‘ and the defenders of traditional local domination, which is to say the family or kingroup, however defined. The question, ultimately, was whether the dominance of and loyalty to the kin could or should be subordinated to a >higher or transcendent ideal or institution - Church, Empire or State. Sima Guang was perfectly clear that it should not, though he also maintained that the Empire itself depended on the strength and stability of the family. The prevalence of his view meant that the imperial government made no serious attempt before the twentieth century to extend its scope or functions in ways that might undermine the local dominance of the gentry. For historians of China the failure of the New Policies has been the turning point that did not turn, quite as controversial and quite as momentous as the triumph of Gregorian reform for their European counterparts. ${ }^{8}$ It did not, however, produce the articulation of such power as an overt political challenge to the imperial regime, or as an alternative to it, in the manner that historians of Europe understand as statebuilding, actual or potential.

Both in Latin Europe and in China the outcomes of these great crises included a comprehensive and authoritative standardisation of the interpretation of their canonical texts, the entrenchment of the position of the learned elites as the interpreters of those texts, and the wider and deeper social diffusion of their interpretations. In Latin Europe these effects were secured, in the wake of Lateran IV, in the first place through the creation of universities, of which the first, at Paris, was granted its first charter in 1215. The regime and culture of the magistri they trained spread by way of the courts and chanceries of the national monarchies, and of other lords, both ecclesiastical and secular, ${ }^{9}$ as well as through the church itself, even to the level of the parish system for which the Lateran decrees established a comprehensive framework. That in turn contributed to the further concentration of local power and a marked intensification of governance, and of cultural values and expectations associated with it, which nobody had planned.

In China a similar effect was produced by headlong growth in the popularity of the imperial examinations. The number of candidates grew exponentially throughout the period, even though the chance of success - that is, of employment in the imperial administration declined from about one chance in two in 1023 to one in 100 in 1156 and one in 200 by $1275 .{ }^{10}$

Derived from Duby, Chivalrous Society; The Knight, the Lady and the Priest; Three Orders; as developed by, among many others, Moore, First European Revolution.

7 Bol, This Culture of Ours, 251-252.

8 E.g. Fairbank, China, 96-8; Huang, China, 118-121; Rossabi, History of China, 184-188.

9 Best approached in English through Murray, Reason and Society and Southern, Scholastic Humanism.

10 Fairbank, China, 95.

medieval worlds $\bullet$ No. $1 \cdot 2015 \cdot 16-24$ 
The imperial bureaucracy, however, was not the only source of employment and influence. To become educated to the extent of sitting the examinations (which presupposed the support of family or patron for many adult years) was in itself a certificate of status and even a degree of competence. The rewards of failure, correspondingly, included those of participation in the establishment and consolidation of local and regional elites. ${ }^{11}$ Since the imperial bureaucracy controlled the examination, and with it the goals and curriculum of education at every level throughout the empire, the canon of writings and approved interpretations, established in the century or so before the Mongol conquests and known today as neo-Confucianism, now dominated traditional Chinese literary culture in much the same way that scholasticism did that of Latin Europe, and for even longer. In combination with commercial growth this cultural intensification helped to underpin formidable concentrations of local power. ${ }^{12}$

These dramatic and momentous episodes in the history of China and Western Europe may be seen as part of a wider crisis of the learned elites of eleventh-century Eurasia. ${ }^{13}$ It has been suggested that the Comnenian emperors, in Byzantium, tried to create an enhanced official cadre in the twelfth century and were frustrated by noble resistance. ${ }^{14}$ The families that provided the rulers of the late ancient and medieval Middle East with their secretaries, clerks and tax collectors had been remarkably successful in maintaining their positions through the Arab conquests and in the Abbasid Golden Age. The Turkish mercenaries to whom the Abbasids began to give way from the late tenth century, however, had both the will and the power to block the independent accumulation of property by their subordinates. To the real and urgent threat of arbitrary and brutal deprivation of both property and office the civilian elites responded by transferring their property to charitable foundations (waqf) which became the informal but indispensable means of access to administrative positions as well as to wider social influence. The endowment of mosques and madraseh and the investment of authority and prestige in transmission from master to pupil, assertedly traced back to the earliest Islamic times, produced, despite the absence of a centralised supporting political structure, a firmly entrenched clerical caste, the ulema, and a sharper and more clearly defined, socially pervasive and effectively enforced Islamic orthodoxy. ${ }^{15}$ Though the Turkish conquests of the eleventh century and after in northern India did not produce mass conversion to Islam, the Brahmans were deprived of the patronage and the intimate relationship with political power hitherto afforded by independent Hindu kingdoms. In the southern part of the sub-continent, on the other hand, temple building on an ever more magnificent scale marked intensifying political competition, and hence a central role for the Brahmans in the articulation and leadership of expanding and increasingly sophisticated regional hegemonies. ${ }^{16}$

With these cases chiefly in mind I concluded that the eleventh and twelfth centuries saw a series of crises among the traditional elites of Eurasia. In response cultural frontiers were sharpened and defined within as well as between the macro-regions, as in Christendom between Latin and Greek, and in Sunni Islam between its four great legal traditions. A reinvigorated Brahminism became prominent in South Asia and what is now called neo-Confucianism

11 Hymes, Statesmen and Gentlemen; Bol, This Culture of Ours, 58-76.

12 Ebrey, Family and Property, 267-8; cf. Bol, This Culture of Ours, 8-10.

13 Moore, Eleventh Century in Eurasian History.

14 Kazhdan and Epstein, Change in Byzantine Culture, 120-133, 192-195; Magdalino, Enlightenment and Repression.

15 Lapidus, Islamic Societies, 273-288.

16 Stein, History of India, 116-129; Stein, Peasant State and Society, 216-253; Heitzman, Gifts of Power, $121-142$.

medieval worlds $\bullet$ No. $1 \cdot 2015 \cdot 16-24$ 
in China. Each region became dominated culturally, and in varying degrees governmentally, by a learned elite which drew its authority from its role as custodian and interpreter of a body of texts held to have been inherited from antiquity, or late antiquity, and, again in varying degrees, of associated ritual and other social practices. Their authority was underpinned by the proclamation and diffusion of new teachings and values, often represented as reform or renewal of the old ones. Accordingly, the learned or clerical elites were differentiated with increasing clarity both within their respective societies and cultures and from each other. In the process the great cultural divisions of settled Eurasia, the world civilizations as we call them, took root and crystallised as the building blocks of modern world history.

That, broadly, is why I wrote in 2009: "Eurasia experienced a Great Divergence in the twelfth century as well as in the nineteenth. The obvious difference is that the first was a divergence of societies and cultures founded on economies in their essentials similar, while in the second rapidly increasing divergence of the economies, with all its consequences, has eroded the differences of culture, to replace them by widening global disparities of wealth and power. Together, however, the two divergences mark an epoch in world history that both made and was made by the complex and changing identities of the citied societies of Eurasia ... $\ll^{17}$

I did not know, of course, that in the same year Walter Scheidel would write, in Rome and China: "In terms of state size, state capacity and state institutions we observe a prolonged process of long term convergence that lasted for many centuries but was eventually replaced by a process of increasing divergence that continued into the early twentieth century. I argue that this allows us to speak of a > Great Convergence < that spanned the entire first millennium $\mathrm{BCE}$ and the first half of the first millennium CE, until a >(First) Great Divergence < began to unfold from about the sixth century CE onwards. ${ }^{18}$

The difference of chronology between Scheidel's divergence and mine is of no account. He is no more likely to insist that the contrast he identified developed at an unvaryingly uniform pace than I am to deny that mine had long and tangled roots. More important are the questions begged by both of us, whether Pomeranz's coinage can be appropriately applied to Eurasian history at all in any part of what we still call the medieval period, and what are the implications of doing so. ${ }^{19}$ The Great Divergence, after all, is the title of a book which not only denied that Europe (or sthe West ‘) had an advantage in development over the citied Asian societies before 1800, but argued that the general antithesis between European and Asian societies - >the west and the rest ` - which underpinned all assertions and explanations of such long-term advantage is unsustainable both empirically and in principle. In doing so Pomeranz showed that explanations of the assumed superiority of European to Asian development have arisen from the comparison of grotesquely over-generalised spatial units - continents and scivilizations carefully selected regions, and even micro-regions. He drew on an immense range of recent scholarship to show how far the traditionally alleged advantages of sthe west depended on

17 Moore, Medieval Europe in World History, 577.

18 Scheidel, Rome and China, 11-12.

19 Pomeranz, Great Divergence. I make no attempt here to consider the extensive discussion to which Pomeranz's thesis has given rise, still less the wider debate on the appropriateness of the swest and the rest d dichotomy and Weberian analyses of it. 
ignorance of sthe rest . He demonstrated consistently and remorselessly that even where an apparent European advantage can be established - in numbers of livestock per capita, for example, or ease of migration from labour-glutted to capital-rich areas, or in access to capital for small enterprises ${ }^{20}$ - it remains difficult to show that there were no compensating alternatives. In short, all claims of long-term cultural advantage are vulnerable to two simple questions: given the length of time and the number of variables involved, does this phenomenon necessarily and inescapably lead from $\mathbf{A}$ to $\mathbf{B}$ ? Even if it did, would it be the only way of getting there? Obvious enough, we may think, for it amounts to the repeated demonstration of a very familiar pedagogic truism, that if you change one thing you change everything.< It should not have been necessary to reiterate that we cannot assert that one observed difference or set of differences at the beginning of the second millennium led ineluctably to another at its end, but Pomeranz's relentless exposure of the persistent failure of scholars to remember it makes sobering reading.

In adopting the phrase Great Divergence I had been particularly impressed, as we so often are in the early stages of comparison, by the dramatic contrast between, on the one hand, the seductive similarities between Latin Europe and imperial China, whatever period may be under observation, and, on the other, the great differences that subsequently became apparent. That clerical celibacy and the institutions associated with it produced a group of people committed to the development of state institutions at the expense of the local power of their families, not just at the time but as an enduring feature of Latin, or western, European society, seemed especially telling, since exactly the opposite appears to have happened in China, and (despite all the other differences among the three) in the central Islamic lands as well. ${ }^{21}$ I identified this as the source of a Great Divergence because it appeared to be at least a condition, perhaps a necessary condition, of the emergence (in Weberian terms) of bureaucratic as opposed to patrimonial government, and with it of the rationality and efficiency that eventually characterised European thought and government. Given the prominence of Weberian rationality in theories of long-term European advantage, and given also that virtually every aspect of >modernisation < as Weber and his followers understood it involved the over-riding of kinship ties and loyalties by wider considerations of responsibility and efficiency, Latin Europe's precocious discovery of an enduring antidote to the iron grip of the family on its ablest siblings was irresistibly seductive.

I still think that the fortuitous creation of a clerical elite whose members were harshly compelled to look to their patrons rather than to their birth-families for sustenance and advancement was at the root of the astonishingly aggressive growth of governance, secular and ecclesiastical, and at all levels, in the Latin Europe of the high middle ages, and that it contributed indispensably to the shaping of European society and culture, as I argued in The First European Revolution. I still think that in this respect Latin Europe was different, and as far as I can see uniquely different, from other Eurasian civilizations at that time. Nevertheless, subjecting my proudly hatched Divergence to the cold shower of Pomeranz's logic exposes the term as a fatally flawed description of the trajectories of change in twelfth-century Eurasia. The simple antithesis between family solidarity and centralising institutions obscures a richer spectrum of relationships among family structures, elite formation and cultural and political development.

20 Pomeranz, Great Divergence, 32-36, 82-85, 180-184.

21 Moore, Property, Marriage and the Eleventh-Century Revolution; Moore, First European Revolution, 65-146. 
In Japan, for example, the old order of Heian was steadily undermined by increasingly assertive local power until it collapsed in the half century following the establishment of the Kamakura bakufu in 1185 into a militarised and fragmented polity. ${ }^{22}$ In this case, however, the structural political changes seem to have preceded, rather than as elsewhere been precipitated by, the dramatic economic growth generated by a shift to more intensive agriculture, which in Japan is associated with the mid-thirteenth century and beyond. ${ }^{23}$ In this case too it is much less easy to discern a cultural leadership as an independent or assertive component of the social order than it is in the cases discussed above.

In Southeast Asia burgeoning agricultural wealth and population growth supported the spectacular development of mighty temple complexes at Pagan and Angkor from early in the eleventh century, to bolster the ritual power of their kings and extend it over hinterlands which formed the cores of modern Burma and Cambodia. ${ }^{24}$ The creation of the elaborate irrigation works that supported them, however, seems not to have been the product of any bureaucratic structure, let alone a centralising one, and the extension of royal influence apparently did not entail attempts to undermine or constrict the power of provincial families. ${ }^{25}$ Nor is there evidence of a crisis among the elites such as I had postulated, in effect by extrapolation from the consequences of intensive growth in China and Western Europe. ${ }^{26}$

The example of Southeast Asia illustrates very well that particular aspects of a society or culture are not always best accounted for by reference to a formal structure of ideas or institutions. There is indeed good reason to consider that the assumption that they will be is Eurocentric in itself, when it is applied for instance to the diffusion of technological improvement through learned academies or societies for the advancement of knowledge, ${ }^{27}$ or to the social influence of sreligion s and the nature and operation of beliefs about the supernatural. ${ }^{28}$ The variety of formal and informal combinations of connections between and influences among economic, social and cultural change during the Great Transformation of Eurasia at the beginning of the second millennium is too rich, and the variety of their permutations too numerous, to accommodate a simple dichotomy. The differences between the ways in which they contributed to the articulation and consolidation of power at local, national and supra-national levels cannot be said in themselves evidently to confer decisive advantage or disadvantage in a fictional race to modernity. That conclusion will not surprise those who are persuaded, as I am, by Pomeranz's rejection of the traditional presumption that in one way or another Europe shad accumulated an internally generated economic edge before $1800 . r^{29}$ They will agree that what can be claimed for the transformation of Eurasia that took place between 1000 and 1300 is not a Great Divergence, but rather the beginning of Pomeranz's 'world of surprising resemblances ' which might be both more accurately and less tendentiously described as a Great Diversification.

22 Souyri, World Turned Upside Down, 29-46.

23 Totman, History of Japan, 107-160; Lieberman, Mainland Mirrors, 398-406.

24 Lieberman, Integration, esp 112-119 (Pagan); 216-33 (Angkor); Reid, Southeast Asia, chapter 2.

25 Lieberman, Integration, 228-230.

26 Lieberman, Mainland Mirrors, 552-553.

27 Pomeranz, Great Divergence, 47.

28 Lieberman, Beyond Binary Histories, 20-21; Moore, Medieval Christianity.

29 Pomeranz, Great Divergence, 16. 


\section{References}

Bol, Peter K., This Culture of Ours: Intellectual Transitions in T'ang and Sung China (Stanford, 1992).

Duby, Georges, trans. Cynthis Postan, The Chivalrous Society (London, 1977).

Duby, Georges, trans. Arthur Goldhammer, The Three Orders. Feudal Society Imagined (Chicago, 1980).

Duby, Georges, trans. Barbara Bray, The Knight, the Lady and the Priest. The Making of Modern Marriage in Medieval France (New York, 1983).

Ebrey, Patricia B., Family and Property in Sung China: Yuan Tsai's Precepts for Social Life (Princeton, 1984).

Fairbank, John King, China: A New History (Cambridge MA, 1992).

Heitzman, James, Gifts of Power. Lordship in an Early Indian State (New Delhi, 1997).

Huang, Ray, China. A Macro History (New York, 1988).

Hymes, Robert P., Statesmen and Gentlemen: The elite of Fu-Chou, Chiang-Hsi, in Northern and Southern Sung (Cambridge, 1986).

Kazhdan, Aleksandr Petrovich and Ann Wharton Epstein, Change in Byzantine Culture in the Eleventh and Twelfth Centuries (Berkeley, 1985).

Lansing, Carol and Edward D. English (eds.) A Companion to the Medieval World (Oxford, 2009).

Lapidus, Ira M., Islamic Societies to the Nineteenth Century (Cambridge, 2012).

Lieberman, Victor, Transcending East-West Dichotomies: State and Culture Formation in Six Ostensibly Different Areas, in: Victor Lieberman (ed.), Beyond Binary Histories. Reimagining Eurasia to c. 1830 (Ann Arbor, 1999) 19-102.

Lieberman, Victor, Strange Parallels. South-East Asia in Global Context, c. 80o-1830. I Integration of the Mainland; II Mainland Mirrors (Cambridge, 2003, 2010).

Magdalino, Paul, Enlightenment and Repression in twelfth-century Byzantium: the Evidence of the Canonists, in: Nicolas A. Oikonomides (ed.), Byzantium in the Twelfth Century: Canon Law, State and Society (Athens, 1991) 359-373.

Miller, Maureen M., New Religious Movements and Reform, in: Lansing and English, Companion, 211-230.

Miller, Maureen M., Clothing the Clergy. Virtue and Power in Medieval Europe, c. 800-1200 (Ithaca, 2014).

Moore, Robert Ian, Property, Marriage and the Eleventh-Century Revolution: a Context for Early Medieval Communism, in: Michael Frassetto (ed.), Medieval Purity and Piety. Essays on Medieval Clerical Celibacy and Religious Reform (New York, 1998), 179-208.

Moore, Robert Ian, The First European Revolution (Oxford, 2001).

Moore, Robert Ian, The Eleventh Century in Eurasian History, Journal of Medieval and Early Modern Studies 33.1 (2003) 3-21.

Moore, Robert Ian, Medieval Europe in World History, in: Lansing and English, Companion, 563-580.

Moore, Robert Ian, Medieval Christianity in a World Historical Perspective, in: John H. Arnold (ed.), The Oxford Handbook of Medieval Christianity (Oxford, 2014).

Morris, Colin, The Papal Monarchy. The Western Church from 1050 to 1250 (Oxford, 1989).

Murray, Alexander, Reason and Society in the Middle Ages (Oxford, New York, 1978).

Pomeranz, Kenneth W., The Great Divergence. China, Europe and the Making of the Modern World Economy (Princeton, 2000). 
Reid, Anthony, A History of Southeast Asia (Oxford, forthcoming 2015).

Robinson, Ian Stuart., Reform and the Church, 1073-1012, in: David Luscombe and Jonathan Riley-Smith (eds.) The New Cambridge Medieval History IV, c. 1002-1198, vol. I (Cambridge, 2004) 268-334.

Rossabi, Morris, A History of China (Oxford, 2014).

Scheidel, Walter (ed.), Rome and China. Comparative Perspectives on Ancient World Empires (Oxford, 2009).

Southern, Richard William, Scholastic Humanism and the Unification of Europe, Vol. 1: Foundations (Oxford, 1995).

Southern, Richard William, Scholastic Humanism and the Unification of Europe, Vol. 2: The Heroic Age (Oxford, 2001).

Souyri, Pierre François, The World Turned Upside Down. Medieval Japanese Society (New York, 2001).

Stein, Burton, Peasant State and Society in Medieval South India (Delhi, 1980).

Stein, Burton, A History of India, 2nd edition (Oxford, 2010).

Totman, Conrad, A History of Japan, 2nd edition (Oxford, 2005). 